\title{
Romanian Postmodern Parody and \\ the Deconstruction of the Literary Canon(s)*
}

\section{Introduction}

The aim of this article is to assess the role of postmodern parody in the deconstruction and the reconfiguration of the literary canon. The canon is a concept and a heuristic metaphor which in Romania has started being discussed in a systematic manner only after 1989.

The Romanian version of postmodernism is undoubtedly indebted to the Western model, but its promoters (writers of the '80s, mainly), have managed to articulate an original poetics, even in the absence of the objective correlative of postmodernism, which is postmodernity (cf. Martin 1995: 3-13). Postmodernism is still a very controversial phenomenon and a much debated notion in Romanian critical discourse. However, nobody can deny that recent Romanian poetry has displayed an outstanding level of intertextual sophistication as well as a remarkable theoretical awareness. The representatives of the '80s wrote a type of poetry which was coincident with (and sometimes critical of) recent developments in linguistics and semiotics (cf. Parpala-Afana 1994), thus conflating intertextuality with interdiscourse and metadiscourse. An important forerunner of their innovations was, as I am going to show, the poet Marin Sorescu (1936-1996).

The scholarship regarding the canon and the problem of canonicity, decanonization and recanonization are overwhelming, and so is the literature dedicated to the other two issues involved, parody and postmodernism. Therefore, I will try to highlight the most important dimensions resulting from the interconnectedness of these concepts, as emerging from this particular corpus of Romanian poetry, with a focus on two volumes, by Marin Sorescu and Mircea Cărtărescu. Some of the findings may have a universal, transcultural value, while others are more culture-specific ${ }^{1}$ and are determined by a peculiar (re)contextualization of the literary movement called postmodernism.

\footnotetext{
* This research was supported by CNCSIS - UEFISCSU project PNII - IDEI, number 757/19.01.2009: Romanian Poetic Postmodernism. 1980-2010. A Semio-Pragmatic and Cognitive Approach. Director: Emilia Parpală. Code: 381 /2008.

${ }^{1}$ For echoes of the canon debate in Romania, see Euresis, 1-2/1998 (Changement du canon culturel chez nous et ailleurs).
} 
Romanian Postmodern Parody and the Deconstruction of the Literary Canon(s)

I should also bring into attention a well-known but unstated "law" concerning parody, namely, that the more canonical (i.e., notorious ${ }^{2}$, respected, studied, imitated) the text or the author is, the more likely it is for it or him to be "celebrated" by a number of parodies, whose "ethos" or "pragmatic range" (cf. Hutcheon 2000: 50-68) will considerably vary. The parodying discourse in Romanian contemporary literature is quite diverse, depending on the parodist's attitude towards the target, or hypotext, or the parodied object (text, genre, style): from the mildly ironic tone to the blatantly or violently sarcastic, parodic deconstruction encompasses a broad spectrum of stylistic, rhetorical and pragmatic possibilities.

\section{The palimpsestic logic of postmodernism}

The postmodern paradigm implies a pluralistic and relativistic vision on canonicity and is based on the overlapping between the national and the international dimensions, or between world literature and national literature (which itself tends to be regarded, more and more, perhaps less threateningly, as cultural specificity). The postmodern "canon" ${ }^{3}$ is presumably more "hospitable" (cf. Nemoianu \& Royal 1991), more open and democratic than the traditional, authoritative canon(s) of the past. Knowing that the literary discourse, in the context of postmodernism, is very much inclined to represent and reflect, meta-discursively, on the very conditions that make it possible, we can ask ourselves what is the role of literature itself, and parodic literature in particular, in the reorganization of the canon(s).

Once admitting that there is a plurality of canons ${ }^{4}$ which are more or less active or influential at a certain moment in a certain culture, I think we can approach the problematic in terms of literary history (cf. Frow 1991), while

\footnotetext{
2 "Parody demands a widely known target which is rich in typical, unmistakable features or idiosyncrasies. Well-known targets have the important advantage that the prospective readers of the parody will presumably realize the intertextual reference, which will enable them to appreciate the parody" (Müller 1997: 136).

3 With so many debates going around, the concept itself can only be conceived "under erasure" ("sous rature"), to use the technique borrowed by Derrida (1976) from Heidegger in order to refer to words that are imperfect but necessary. The same ironic reading is required by other important concepts: value, norm, standard (the canon as norm or rule and as measurement and exemplarity, the paragon of aesthetic excellence), or literariness as the quidditas of literature etc. Current discussions on the canon are carried out in the aftermath of deconstruction, in a "post-canonical" age, and are influenced by the anti-essentialistic orientation of postmodernism.

${ }^{4}$ For example, the aesthetic, the curricular canon, the critical canon, but also the alternative, unofficial or semi-official lists, etc.
} 
acknowledging the implications of value judgments and critical authority in the configuration of literary hierarchies. Mapping the canon might be primarily the task of critics, theoreticians and literary historians, but literature itself is often a locus for the metadiscursive analysis of literary classifications and the assumptions behind them (for example axiological criteria and the ideological biases that are inherent in the process of canon-formation $)^{5}$, and it can undertake this analysis in a more explicit or implicit manner, in a monologic, consensual and non-disruptive way, or in a polyphonic, polemic, ironic kind of way.

The inextricable interaction and also overlapping of national and international literature (especially in the self-definition of a national tradition on the background of already existing cultural patrimonies) should also be taken into consideration. The issue of selection comes about and it becomes clear that the world canon as received by Romanian literature in its more recent (modern) history has, first and foremost, a strongly-defined core (somewhat limited in scope), which is Western-centric so to say, meaning that the Western intertextual landmarks (or models) prevail, and the more dynamic "margins", characterized by open-endedness and hospitality towards alternative styles, towards "minor" or second-rate authors deserving re-evaluation as well as references to more "exotic" and less known foreign literatures.

The literary discourse has its own ways of internalizing the canon debate: metonymically, by allusions, echoes, references, quotations, but also metaphorically, by complex rewriting strategies able to generate palimpsests: pastiche, parody, bricolage, collage, transpositions, à la manière de $^{6}$ etc. But even this does not exhaust the possibilities of meta-canonical literature. The canons of classical theory are even more deeply embedded in the literary fabric: Aristotle's and Horace's concepts have been for so long a part of the way literature and literariness are conceived in European literature, that we can no longer take into account only the body of literature per se, but also the extent to which the literary discourse is informed by the metadiscourse (theory, aesthetics, poetics etc.). In this context, parody is one of the most powerful polemical tools that literature detains and, particularly in postmodernism, the metaliterary level and the interliterary dimension of this genre (sometimes described as a strategy, a device) are foregrounded.

\footnotetext{
5 Thus, from the point of view of national cultures, I agree with Guillory (1993) that canons are a problem of "cultural capital", and this will result also from the texts I am about to consider.

${ }^{6}$ I.e., various intertextual and hypertextual strategies of the kind theorized by Genette in his synthesis on palimpsests (1982).
} 
Romanian Postmodern Parody and the Deconstruction of the Literary Canon(s)

Since always, we could say, national literatures have taken up models, patterns, concepts and ideas from other ethno-cultural traditions and they have made these borrowings their own. This process of appropriation and voluntary assimilation (and re-creation from a new perspective) entails a dynamic and dialogic approach of interliterary relations, one that would transcend a too narrow, unidirectional and passive view as proposed by the traditional model of influence and reception.

Certainly, power relations are bound to develop in such an interactional, communicational model, no matter how flexible a particular account of the canon and Weltliteratur wants to be. Wherever there is appropriation and adaptation, there is also détournement, deviation, and recontextualization, as well as "abusive" and nevertheless contractually-sanctioned reinterpretation.

Parody as a dialogic and intertextual strategy usually activates the polemic energies inherent in the way the receiving culture relates to the "hegemonic", unavoidable model represented by a more prestigious ${ }^{7}$ culture. The decanonizing parody might also fulfil the parodist's need to come to terms with the so-called "anxiety of influence" (cf. Bloom 1973). At the macro-level of international literary relations, the dynamic of imitation is counterbalanced by emulation.

As all binary oppositions, the dichotomy national vs. universal is often undermined in the postmodern discourse, as we can see from the following example by Simona Popescu - I couldn't care less..., an excerpt from her book Green Care Works or My Plea for Poetry:

[...] Yesterday Dominique asked me what were the things that connects me, connects us, Romanian writers.

After a while some guy is going to call me bad names because I don't support national specificity.

$\mathrm{Me}$, when I read Koch I couldn't care less if he is an American writer

I couldn't care less about what is that connects him to American writers

[...] And Pound saying to Harriet Monroe:

Are you for American poetry or for poetry?

Are you for Romanian poetry or for poetry?

Tell me!" (Popescu 2006: 234)

\footnotetext{
7 "A culture becomes a source by prestige" - this is one of the "laws" of cultural interference identified by Itamar Even-Zohar (2005: 10).

${ }^{8}$ My translation of: „Ieri m-a întrebat Dominique care sunt/ lucrurile care ne leagă pe noi, scriitorii români./ Poate o vreme unul mă va înjura că nu suș̦in/ specificul național./ Eu când îl citesc pe Koch
} 
Here the poet explicitly addresses the issue of personal vs. collective identity and the author's alleged sense of belonging to a national culture (which she rejects as a cliché and an oppressive demand from the outside, from the body social and politic). Her way of reading poetry transcends these types of didactic and ideological categories. And the argument she uses to consolidate her position is the quotational intertext (Ezra Pound), which eventually undermines her subversive stance, because it implies the recourse to authority. Instead of World poetry as an alternative to the much too narrow national corpus, she advances a new "concept" (or, better said, a mock-concept), namely, Panpoetry (Popescu 2006: 226) ${ }^{9}$. I think she prefers this because in her neo-surrealist vision, poetry is everywhere, meaning that it is not only transnational, but also transgeneric, transdiscursive and trans-ontological, so to speak: it is not confined to the lyric genre, or to the linguistic code, it is present in the very fabric of the quotidian, as a mode of perception and re-creation of the world.

\section{Parodic decanonization and deconstruction:}

\section{the canon "under erasure"}

While Fredric Jameson (1991: 17-18) has characterized the postmodern as a period when the writers have "nowhere to turn but to the past: the imitation of dead styles, speech through all the masks and voices stored up in the imaginary museum of a now global culture" and parody is indistinguishable from pastiche, Linda Hutcheon has insisted that parody's ethos should be considered as "unmarked, with a number of possibilities for marking" (Hutcheon 2000: 60). She has not excluded the polemic dimension of this form and its potential for dedoxification, especially in modern and postmodern times, although the mocking and ridiculing intention is not necessarily directed towards the explicit target of the ironic palimpsest ${ }^{10}$. Along with Margaret Rose's account of parody (1979), which emphasizes the meta-literary aspect involved in the workings of this mode, a very useful model for understanding the postmodern difference is

puțin îmi pasă că e scriitor american/ Puțin îmi pasă ce-l leagă pe el de scriitorii americani.//Eşti pentru poezia româneasca sau pentru poetry?/ Zi!”

9 The etymology she advances is, of course, playful: all the artists are, "in the eyes of God, (Peter) Pan's children! Hence, Panpoetry" (Popescu 2006: 234).

10 Also, Ihab Hassan (1986: 502) lists decanonization among the defining features of postmodernism, along with indeterminacy, fragmentation, selflessness/depthlessness, the unpresentable/ unrepresentable, irony, hybridization, carnivalization, performance/participation, constructionism and immanence. 
Romanian Postmodern Parody and the Deconstruction of the Literary Canon(s)

Gary Saul Morson's theory about parody, counterparody and metaparody: "[...] when readers do not know with which utterance they are expected to agree, or suspect that the second utterance may be no more authoritative than the first - then we do not have parody, but another dialogical relations, metaparody" (1989: 68).

Of course, we should also try to assess what "decanonization" stands for. Is it an actual, palpable effect, the outcome of a very efficacious polemic argumentation? There are some radical parodies which could suggest this thing, but in postmodernism, parody functions in a paradoxical, or at least ambivalent way, as subversion and re-assertion, homage, celebration of the parodied object $^{11}$. Could decanonization mean a radical uprooting of established values from the public consciousness (a shattering of idols, as it were...)? This does not seem to happen, however, since this type of irreverent gestures have already been homologated in literary history under inoffensive labels such as "avantgarde", or "postmodernism" or "experimentalism", along with other (macro)styles and their way of approaching cultural value. Moreover, parody's particular grammar and the readers' ability to process and qualify a deconstructive verbal ${ }^{12}$ act as "parody" might surreptitiously go against the intended serious, committed polemic, because of the very conventionality of the genre, and also because of its primarily ludic orientation (cf. Chambers 2010), as well as its reputation of frivolity.

\section{Marin Sorescu's volume of parodies, Alone among Poets}

I want to draw a parallel between the function that The Levant (1990) by Cărtărescu has had in reshaping our vision of the canon and the one of Marin Sorescu's debut volume Alone among Poets. Parodies (1964), where the autochthonous tradition and the world classics ${ }^{13}$ are equally targeted; high and low references are serenely juxtaposed, and the respectable clichés of certified styles are no less derided than the absurd "originalities" and novelties of

\footnotetext{
${ }^{11}$ Perhaps Cervantes' Don Quijote is a more appropriate illustration for parody's "power" as regards, if not canons themselves, then literary fashions and some broader literary configurations of the generic/ architextual type, such as the chivalric pseudo-literature that the author intended to undermine. However, despite the writer's unequivocal parodical and satirical purposes, there is a degree of ambivalence even there.

12 For a very broad understanding of parody as a basic linguistic act and a form of communication, see Rossen-Knill and Henry (1997) and Dentith (2000).

${ }^{13}$ Villon, Petrarch, La Fontaine, Baudelaire, Esenin.
} 
untalented debutants or the silly texts of pop music ${ }^{14}$. Encouraged by the ideological "thaw" of the decade, Sorescu's literary comedy implicitly reinstated the criterion of literariness and aesthetic value which was to become prevalent until the late eighties.

In the volume, most of the foreign hypotexts are mentioned with a paratextual indication of the translators, which suggests that the reader is somehow invited to decode the parody by focusing on the Romanian translation of the (Russian, French, Italian) original. Translation is an instance of reception and interpretation inasmuch as it is an intertextual method. In the case of Serghey Esenin, Sorescu juxtaposes two parodies of two different translations of the same poem (The Calf), one by George Lesnea and the other one by Zaharia Stancu (Sorescu 1990: 49-50). The first has a slight folkloric undertone, while the second is strikingly modern. An implicit statement about stylistic diversity could be read into this, and also an indication as to the canonizing power of translation, but also as to its distorting potential. Sonnet 31 by Petrarch (ib. 51) has become so schematic and trivial in the parodic version, that we cannot but infer a critical intention directed not to the hypotext proper, but to Lazăr Iliescu's bad translation.

As a form of "naturalization" and adaptation of a foreign discourse, translation operates as an intercultural mediator. But the translator's personal "contribution", either good or bad, to the overall rhetoric effect is what seems to interest Sorescu the most. The Ballad of the Plump Margot in its parodic guise is obviously an eulogy of both Villon's exuberant language and that of his Romanian translator, Romulus Vulpescu ${ }^{15}$.

The only poem in the section where the name of the "translator" is not mentioned is a parody after La Fontaine's The Grasshopper and the Ant (ib. 43). This lack of interest in the translation which mediates between the classics and our own "homely" ${ }^{16}$, domestic literature suggests that in this case parody's stake lies elsewhere, perhaps in the way various cultural periods relate to the archetypal situation of the fable and its clash of values: the dichotomy art/entertainment vs. trade (or "real" work), aestheticism vs. utilitarianism has been differently approached in different epochs. Resorting to a violent parodic reversal of meaning, Sorescu turns the starving artist into a bully, who, very

\footnotetext{
${ }^{14}$ Which in Romanian is, literally, "easy music".

15 In fact, where for the other translations the paratext was a neutral indication of the source, here in the same place we find the dedication: "to my friend, the poet Ro.Vul" (ib. 46).

${ }^{16}$ This section of the volume is actually entitled Clasicii universali la noi acasă (The World Classics in Our Home).
} 
much annoyed by the hardworking ant's refusal to lend him some wheat, decides to beat her up. After that, she "gladly" agrees to lend him everything he wants.

Literariness or poeticity understood as the purported "essence" or "nature" of literature/poetry is the underlying theme of the parodic deconstruction, being ultimately revealed as on the one hand timeless and universal and on the other hand historically and culturally determined.

The contexts in which the two books (Alone among Poets and The Levant) were written are also important in order to better understand the motivations of both parodying gestures. However, the standpoint of Sorescu's complicitous critique (either of the lofty, truly valuable cultural "monuments" or of the pseudo-literary teratology of the '50s) is different from Cărtărescu's sympathetic, carnivalesque rewriting of the modernist canon.

Despite Sorescu's anticipation of the Romanian programmatic postmodernism of the ' 80 s, his position is rather conservative, or, at least, we could say that he upholds some clear standards of artistic value - maybe highmodernist or just classical - as opposed to both the grotesquely ideologized proletkultist productions and the poorly crafted attempts of modernizing the poetic discourse (and I should say that when a very shallow notion of the "avant-garde" in poetry meets the bad taste of kitsch sensibility, the results are not far from the parodist's diagnosis). While striving to design a new outline for a truly aesthetic canon, Sorescu also tries to find his own identity (we must not forget that he makes his debut with this volume $)^{17}$ and it is somewhat ironic that his option would be, in the following volumes, for the more straightforward, conversational type of poetry that he ridicules here under the masks of Petre Stoica, Pablo Neruda, Aurel Gurghianu, Horia Zilieru etc. His incomprehension would not be easy to account for, if it were not for the very complicated psychology of the parodying artist himself. He seems to unveil the bombastic rhetoric underlying some of the modern, more direct and simpler experiments in poetry, which were also inclined to treat trivial events as epiphanies. Here is an example, the Song for my autovehicle, vanished in darkness, attributed to Pablo Neruda:

\section{[...] A vast feeling caresses my vast soul}

Thinking that all these components are automatically oiled

With the best oil in the world [...].

17 Conversely, Cărtărescu "crowns" his poetic career with the Levant, before giving up poetry altogether: he was ready to write prose from now on. 
POPESCU

Look at him, humankind, driving off and leaving me here

The ruthless Yankee!

But I don't mind a bit about his four speeds

Here, I take this shortcut towards the future,

Aware that the straightest way between two points is, no matter what,

The shortcut.

Bearing on my shoulders the universe of my poems,

Where you, people, are finding yourselves, without the Yankees! (Sorescu 1990: 94) $)^{18}$

Such derisive stylizations look like very nasty, malicious and unfair parodies (rewriting based on misreading and distortion of the original), and we would be compelled to interpret them that way if we did not accept that Sorescu employs the term parody in a sometimes misleading way - at least, for the common perception. But his ambiguities prove in fact that there is a more unusual version of parody, the so-called reverential or non-ridiculing parody, which is often mistaken for pastiche.

\section{Mircea Cărtărescu's mock-epic The Levant}

Levantul (The Levant) (1990) is a perfect illustration of that ambivalent deconstruction, of the uncanny conciliation of irony with nostalgia and of the metaparody which is characteristic to postmodernism. An obvious celebration of Romanian and world poetry, this postmodern mock-epic is nevertheless much more than a mere mixture of pastiches, stylizations and "exercises de style". The protagonist is called Manoil and his initiatic voyage finds its culminating point in the episode Hallucinaria: according to the epic archetype of descensus ad inferos or katabasis, the epic heroes will descend, in a key-point of the action, into hell (Hades), in order to find out the ultimate truth about themselves and their destinies as leaders of their people. Cărtărescu's alter-ego, Manoil, enters a fantastic realm, filled with poetic voices of the past (which, in fact, to Manoil is the future, thus recalling the play with the temporal planes in

\footnotetext{
${ }^{18}$ My translation of the Romanian original: "Un vast sentiment îmi mângâie vastul suflet/ Gândind că toate aceste piese sunt unse automat/ $\mathrm{Cu}$ cel mai bun ulei din lume [...]/ Priviți-1, omenire, cum pleacă şi mă lasă/ Neomenosul yankeu!/ Dar mie puțin îmi pasă de cele patru viteze ale lui/ Iată, o iau pe această scurtătură spre viitor,/ Conştient că drumul cel mai drept dintre două puncte este tot/ Scurtătura./ Purtând pe umeri universul poemelor mele,/ În care vă veți regăsi voi, oameni, fără yankei!"
} 
the Sixth Chant of Vergil's Aeneid) and he ends up by encountering his own self in the guise of The Levant's author.

The Romanian poetic canon (here epitomized by Eminescu, Arghezi, Barbu, Bacovia and Blaga) is being re-consecrated and re-affirmed, legitimized, but the eulogy is not without a certain shade of ambiguity: the statues of poets who come to life and start reciting suggest something far too solemn and frozen for the postmodern taste (which is defined by dynamism and proteism). This statuesque imagery connotes also a funerary notion, not just the reverence of posterity towards the sublime values of the canon. There is definitely ambivalence, for this is a living, glossolalic and polyphonic canon and at the same time it has the disturbing rigidity of any public and institutional cult.

Each of the great masters ${ }^{19}$ is identified by a series of features and indices which are supposed to help the reader in the inference process. Guided by the nymph, Manoil passed through various chambers, until they reached an exquisite one, adorned with diamonds; there he finds "a single statue on a giant pedestal”, a "dark gentle-eyed statue" (Cărtărescu 1998: 108). This is, unmistakably, Eminescu, the Romantic poet, the uncontested "centre" of the Romanian canon. After that, the chamber is getting larger and the novice sees four huge statues. The first is characterized as "versatile: not it's bronze, not it's clay,/ Now it's burning like a torch, now it's only charcoal./ Filters he makes out of venoms, cold pearls out of mildew". [...] (Ib.108-109) ${ }^{20}$ This one should be recognized as Tudor Arghezi, the author of Mildew Flowers. In a similar manner, the other iconic figures of the inter-war (modernist) poetic canon are metonymically and intertextually featured, through phrases and quotations taken from their works. Among the arabesques on the ice walls in this enchanted realm, the statues of Ion Barbu, George Bacovia and Lucian Blaga are coming to life to recite a poem (which is Cărtărescu's pastiche after their respective styles) and then become frozen again. For example, Ion Barbu, the poet-mathematician, appears "lost in abstractions, heptagons and lights" (ib. 110-111), and holding in his hands Craii de Curtea Veche by Mateiu Caragiale and the work of Edgar Allan Poe, two writers he greatly admired. Lucian Blaga, the poet-philosopher, author of I do not crush the world's corolla of wonders, is

\footnotetext{
19 The mystagogical angel who guides Manoil in his visionary travel even lectures him, didactically, on the importance of the modernist canon and on what we could call the dialectic of continuity and discontinuity in the intergenerational dynamic: "These four, Manoil,/Are the masters of poetry in that versatile century, XX" (Ibidem: 114)-(Ceștia patru, Manoil,/Sunt măiestrii poesiei vacului cel versatil, $\mathrm{XX}$ ").

${ }^{20}$ This is my unrhymed version of the Romanian original: Prima statuă-i versatilă: acum bronz, acuma lut e,/ Acum arde ca o torță, acum e doar jărăgai./Filtre face din veninuri, perle reci din mucigai."
} 
POPESCU

presented as a "hermit" holding a flower which scatters its chalice in the wind [...]" (ib. 113).

A notable thing, in this combination of eckphrasis and prosopopeia, is the way in which the defining characteristics of the authors' style are projected on their sculptural simulacrum, as evidence to the postmodern poet's refusal of depersonalizing the writing process. The modernist, poststructuralist claim of "the death of the author" (Barthes 1977) is perhaps equally incriminated, along with the other extreme, the idolatrous representation of canonical items, which either monumentalizes the work of art (through the cultural policies of state propaganda), or commodifies it (by subjecting it to the mechanisms of consumer society).

Although the canonical authors invoked in the Levant are Romanian, true iconic figures of the critical and curricular tradition, the consecration, as well as the relativization of their axiological status by the postmodern writer is undertaken from the viewpoint of a transnational representation of literature and literariness ${ }^{21}$. All these authors are so much imbued with the European models, that we can hardly consider this focus on the Romanian canon as ethnocentric. From its very beginnings, Romanian literature was a palimpsest, a cultural hybrid.

In the intertextual and interliterary configurations making up the canons, the dichotomy between national/local and universal/international/global is on the one hand subverted and on the other hand reinforced, to the extent that each term is used as a means to relativize the other (meaning that the national "standard" is seen in a new light because of the cultural shock brought about by the grafting of difference, and the universal, transcultural ideal is also destabilized by the excesses of cultural specificity). This becomes even more obvious in the literary parodic practices of contemporary literature (especially in Cărtărescu's experiments with dialogized heteroglossia in The Levant). The unusual language he creates, as a mixture of archaic and modern elements, will bring a peculiar imprint, the mark of genuine difference, on the pattern of an outdated genre (the epic). I should stress the fact that this process is very much emphasized in the workings of parody, which relies, basically, on a poetics of

\footnotetext{
21 Without in any way remaining confined in a sort of facile irreverence to the local canonical authorities, the so-called eightiards "revered" different literary idols, either the Romanian playful or mannerist poets who were generally deemed as minor or less important (Leonid Dimov, Mircea Ivănescu) or some foreign poets (mostly American), who were more or less known through very scarce translations in anthologies or the semi-clandestine circulation of their books in the original (for example, Allen Ginsberg, Lawrence Ferlinghetti, Frank O’Hara, etc.).
} 
difference or differential rewriting. For example, when using very idiomatic language in the paraphrase of notorious French, English works, or when paralleling and contrasting the prestigious Western model with a very "ethnic" local author, genre or style... In this case parody is replaced by the genre called travesty, where the national element plays the role of the "low" style used in order to comically transpose the "high", heroic elements of the hypotext. A culture is seen through the eyes of a different culture and its image is unavoidably distorted and misrepresented but, at the same time, it is also enriched $^{22}$.

In this mythical narrative, chronology becomes teleology, so we could say that the author endorses a traditional, pre-modern perception of the canon and literary "evolution". The ambivalence remains, in fact, irreducible until the very end and it is very much controlled and premeditated by the authorial persona.

In terms of literary imagery and cognitive metaphors for representing the canon, Cărtărescu's ambiguous portrayal of the "masters" as statues is quite interesting. Another compelling aspect is the implication that the poet himself, the "disciple", the follower, gives them life, reanimates them by his intertextual accolade: the discourses articulated by the statues are not literal quotations from their works, but Cărtărescu's own stylizations, pastiches, in the manner and on behalf of these authors, so as to be recognized as idiosyncratic and at the same time hybridized with the postmodern poet's own voice. Cărtărescu proves that the actual and genuine life (and vitality) of a poetic style resides, paradoxically, in its imitability, which derives, actually, from the work's quality of being influential.

Although the worship of statues suggests idolatry, only when these statues are given a voice do they become alive again, provided they speak to someone, as it actually happens in this epic poem. So the prerequisite of addressivity stays in force even in the case of canonical utterances. They are canonical inasmuch as they are "audible" and intelligible for people in other eras.

If we understand deconstruction as reading "under erasure", without destroying or deleting the referent, but allowing it to go on, to be visible, we can better assess the role of irony and parody in the postmodern era. The parodic stylizations in The Levant are as much a celebration of the canon as they are a Saturnalian subversive anti-text of the authoritative discourse attributed to the canonizing institutions. When we say that parody "deconstructs" the canon we

22 Cf. Bakhtin's "intonational quotation marks" (1981: 44) which can be extrapolated to the dialogical nature of intercultural relationships; inverted commas, as we very all know, can also be used as scare quotes or signals of irony. 
POPESCU

imply that it denounces the canon as a cultural construct. But this "denunciation" is not radical. Instead, the carnivalesque rewriting remains in the ambiguous realm of play and multivocality, so that it is not about taking full responsibility for one's utterance and enunciation, as in the case of critical or theoretical discourse ${ }^{23}$.

The carnivalesque and carnivalization (cf. Bakhtin 1984: 122) as temporary reversal of cultural hierarchies could therefore work as an appropriate analogy for the ambiguous processes of postmodern decanonization. Of course, there are probably many examples in various cultural contexts where decanonization can result in an actual change in the canon or recanonization (another canonical list, a different axiological scale), and the delegitimizing impulse of the parodic action can be either temporary as the carnivalesque gestures (when, for example, they are directed to the great works, which ultimately remain untouched by the "blasphemy") ${ }^{24}$ or it can equally result in a permanent discreditation of an oeuvre, an author or a genre ${ }^{25}$.

\section{Conclusions}

In terms of formal and structural relations between texts, the deconstructionist poetics of parody involves: the laying bare of devices, hence the unveiling of the "grammar" of the targeted text, style, genre, code.

Apart from these somehow universal mechanisms pertaining to the very functioning of the parodic genre, postmodern parody can also act as a palimpsestic, "second-order" mode of calling into question the issue of canonicity, both in its national and in its international dimension. By the interaction with

\footnotetext{
${ }^{23}$ A little more should be said about literary deconstruction as opposed to the polemic conducted within the scholarly, non-literary discourse (criticism, theory). As some scholars have shown, the two main positions regarding the canon (especially in The United Stated and in the West in general), the pro-canon side and the reformists' side are actually closer than we would suspect (cf. Kolbas 2001: 26). The conservative wing (well represented by Bloom 1994) and the revisionist wing, share similar ideological assumptions about literariness, about the function and impact of literature or about the relation between ethics and aesthetics. I think that the literary discourse, due to its special ontological status, is able to avoid being held accountable for some logical aporias, and this happens precisely because it relies on them and foregrounds them. At the same time, for the very same reasons, the metaliterary deconstruction, though not totally devoid of persuasive force, will not contribute to the cultural debate in the same way and on the same terms as the non-literary polemic. Parody can be a misreading of its hypotext, according to a pragmatic contract assumed by both parties (parodist and addressee).

24 When they are not, on the contrary, "fortified" and their canonical aura enhanced by this ineffectual disparaging, perceived only as a kind of primitive ritual of laughter.

25 See, for the latter case, the treatment of chivalric novels by Cervantes in Don Quijote.
} 
satire, the parodic practices displayed by the postmodern corpus also draw attention to the ideological underpinnings of canon formation.

Parodic intertextuality in the two key-examples analyzed here aims at national but also Western hypotexts, thus emphasizing the Romanian ambivalent relationship with both foreign models and the country's cultural icons. The decanonizing potential of parody works on various levels, engaging the canon's complexity and multi-layeredness: thus, it can entail ideological, aesthetical, identitary and imagological consequences (concerning collective identity, or the culture's self-image).

Another important issue is the actual canonization of parody by postmodernism, so that this literary mode is no longer seen as a minor, inconsequential, merely entertaining form. Of course, this process of rehabilitation of parody has begun with the formalistic accounts of "literary evolution" and the literary system but it is radicalized in the context of postmodernism.

Postmodernism challenges and changes the relationship with history (and literary history), by abandoning (at least apparently, or declaratively) the modernist imperative of permanent renewal. The connection between parody and the paradigm shifts allows us to consider the recourse to parody as a sort of rite of passage, in the realm of culture.

The postmodern corpus faces us with the paradox of a non-committal, evasive polemic, in the shape of metaparody, and the differential, "under erasure" reinscription of the doxa, tradition, conventions, clichés and the reified strategies of codified discourses and styles. Cultural/national specificity and the ideal of universality are being undermined but also recuperated by the rhetoric of postmodern parody.

\section{References}

Bakhtin, M. M. 1981. The Dialogic Imagination. Four Essays. Ed. by Michael Holquist. Trans. by Caryl Emerson. Austin: Texas University Press.

Bakhtin, M. M. 1984. Rabelais and His World, Trans. by Hélène Iswolsky. Bloomington: Indiana University Press.

Barthes, R. 1977. The Death of the Author. - Image, Music, Text, Trans. by Stephen Heath. New York: Noonday, 142-148.

Bloom, H. 1973. The Anxiety of Influence. New York: Oxford University Press.

Bloom, H. 1994. The Western Canon. The Book and School of the Ages. New York: Harcourt Brace \& Company.

Cărtărescu, M. 1998 [1990]. Levantul. Bucureşti: Humanitas.

Chambers, R. 2010. Parody. The Art that Plays with Art. New York: Peter Lang. 
POPESCU

Changement du canon culturel chez nous et ailleurs. 1998. - Euresis. Cahiers roumains d'études littéraires, 1-2. Bucarest: Univers.

Dentith, S. 2000. Parody. New Critical Idiom. New York: Routledge.

Derrida, J. 1976. Of Grammatology. Trans. by Gayatri Chakravorty Spivak. Baltimore \& London: The Johns Hopkins Press.

Even-Zohar, Itamar. 2005. Laws of Cultural Interference. - Papers in Culture Research. http://www.tau.ac.il/ itamarez/works/papers/papers/laws-of-culturalinterference.pdf.

Frow, J. 1991. Postmodernism and Literary History. - Harvard English Studies (Theoretical Issues in Literary History), 16, ed. by David Perkins, 131-142.

Genette, G. 1982. Palimpsestes ou la littérature au second degré. Paris: Seuil.

Guillory, J. 1993. Cultural Capital. The Problem of Literary Canon Formation. Chicago: University of Chicago Press.

Hassan, I. 1986. Pluralism in postmodern perspective. - Critical Inquiry, 12, 3, 503-20.

Hutcheon, L. 2000 [1985]. A Theory of Parody. Illinois: University of Illinois Press.

Jameson, F. 1991. Postmodernism or the Cultural Logic of Late Capitalism. London: Verso.

Kolbas, E. D. 2001. Critical Theory and the Literary Canon. Ann Arbor: Michigan University Press.

Martin, M. 1995. D'un postmodernisme sans rivages et d'un postmodernisme sans postmodernité. - Euresis. Cahiers roumains d'études littéraires, 1-2, Le postmodernisme dans la culture roumaine. Bucarest: Univers, 3-13.

Morson, G. S. 1989. Parody, History and Metaparody. - Morson, G. S. \& C. Emerson, eds., Rethinking Bakhtin: Extensions and Challenges Illinois: Northwestern University, 63-86.

Müller, B. 1997. Hamlet at the Dentist's. Parodies of Shakespeare. - Müller, B., ed. Parody: Dimensions and Perspectives. Amsterdam: Rodopi, 127-154.

Nemoianu, V. \& R. Royal, 1991. The Hospitable Canon. Essays on Literary Play, Scholarly Choice, and Popular Pressures. Amsterdam: John Benjamins.

Parpală Afana, E. 1994. Poezia semiotică. Promoția 80. Craiova: Sitech.

Popescu, S. 2006. Lucrări în verde sau pledoaria mea pentru poezie. Bucureşti: Cartea Românească.

Rose, M. 1979. Parody/Metafiction. London: Taylor \& Francis.

Rossen-Knill, D. F. and R. Henry. 1997. The pragmatics of verbal parody. - Journal of Pragmatics, 27, 6, 719-752.

Sorescu, M. 1990 [1965]. Singur printre poeți. Parodii. Bucureşti: InterCONTEMPress. 